\title{
Genetic elements associated with antimicrobial resistance among avian pathogenic Escherichia coli
}

\author{
Amal Awad', Nagah Arafat ${ }^{2}$ and Mohamed Elhadidy ${ }^{1,3^{*}}$
}

\begin{abstract}
Background: Avian-pathogenic Escherichia coli (APEC) are pathogenic strains of E. coli that are responsible for one of the most predominant bacterial disease affecting poultry worldwide called avian colibacillosis. This study describes the genetic determinants implicated in antimicrobial resistance among APEC isolated from different broiler farms in Egypt.
\end{abstract}

Methods: A total of 116 APEC were investigated by serotyping, antimicrobial resistance patterns to 10 antimicrobials, and the genetic mechanisms underlying the antimicrobial-resistant phenotypes.

Results: Antibiogram results showed that the highest resistance was observed for ampicillin, tetracycline, nalidixic acid, and chloramphenicol. The detected carriage rate of integron was 29.3\% (34/116). Further characterization of gene cassettes revealed the presence gene cassettes encoding resistance to trimethoprim (dfrA 1, dfrA5, dfrA7, dfrA 12), streptomycin/spectinomycin (aadA1, aadA2, aadA5, aadA23), and streptothricin (sat2). To our knowledge, this the first description of the presence of aadA23 in APEC isolates. Analysis of other antimicrobial resistance types not associated with integrons revealed the predominance of resistance genes encoding resistance to tetracycline (tet $A$ and tetB), ampicillin (bla $\left.a_{\mathrm{TEM}}\right)$, chloramphenicol (cat 1), kanamycin (aphA1), and sulphonamide (sul1 and sul2). Among ciprofloxacin-resistant isolates, the $583 \mathrm{~L}$ mutation was the most frequently substitution observed in the quinolone resistancedetermining region of gyrA (56.3\%). The bla $a_{\mathrm{TEM}}$ and $b a_{\mathrm{CTX}-\mathrm{M}-1}$ genes were the most prevalent among APEC isolates producing extended-spectrum beta-lactamase (ES $\beta L)$.

Conclusions: These findings provided important clues about the role of integron-mediated resistance genes together with other independent resistance genes and chromosomal mutations in shaping the epidemiology of antimicrobial resistance in E. coli isolates from poultry farms in Egypt.

Keywords: Antimicrobial resistance, E. coli, Poultry, Integron, Genes

\section{Background}

Avian colibacillosis is an extraintestinal infection associated with upper respiratory tract infection typically air saculitis that can evolve into multiple lesions in different organs as polyserositis, cellulitis, salpingitis, perihepatitis, peritonitis, septicaemia, and death. These cause severe economic losses in the poultry industry due to the remarkable number of morbidities, mortalities, slaughter

\footnotetext{
*Correspondence: mm_elhadidy@mans.edu.eg

${ }^{1}$ Department of Bacteriology, Mycology and Immunology, Faculty of Veterinary Medicine, Mansoura University, Mansoura 35516, Egypt Full list of author information is available at the end of the article
}

condemnation, and reduced productivity of the affected birds [1].

To reduce the high incidence and mortalities caused by avian colibacillosis in poultry farms, antimicrobials are considered as one of the gold choices among veterinarians in the poultry industry. However, in Egypt and other developing countries, antimicrobials are not only used for therapeutic reasons but also for prophylactic purposes in disease prevention and growth promotion. Such overuse and/or misuse contribute to the development and spread of antimicrobial resistance (AMR) among poultry flocks, leading to emergence of multiple drug 
resistance (MDR) pathogens [2]. These MDR profiles can be transmitted to human through the food chain adding serious burden to human health. In addition, several studies supported the growing evidence that antimicrobial resistance can occur in the absence of selective pressure, highlighting the crucial role of antibiotic resistance genes in the development of MDR bacteria [3]. The acquisition and dissemination of these antibiotic resistance genes is mainly mediated by horizontal gene transfer in which several mobile genetic elements facilitate this process, including plasmids, transposons, integrons, and bacteriophages [4]. Integron is one of the major genetic elements by which bacteria can capture or excise one or more resistance gene cassettes by site-specific recombination. The mobilization of integron through transposons, plasmids, or other mobile genetic elements enables the spread of integrated resistance genes. This potentially facilitate the integration of almost all antimicrobial agents through the integron and increase the diversity of integrons in isolates from different sources, including human, avian, livestock, and environmental isolates [4-6].

The aim of this study was to determine the antibiotic susceptibility phenotypes of APEC isolated from different broiler farms in Egypt and to evaluate the association of observed phenotypes with the acquisition of integron mediated resistance gene cassettes or other resistance genes and chromosomal mutations located outside the integron.

\section{Methods}

\section{Bacterial isolates}

In total, 116 APEC isolates recovered from 400 different samples were assayed. Samples were obtained from liver, lungs, air sacs and spleen from chicken with typical lesions of colisepticemia and were collected from 28 different broiler farms located in different geographic areas of Dakahlia Governorate in 2014 and 2015. Samples were cultured onto eosin methylene blue (EMB) agar (Oxoid, Basingstoke, UK) and incubated for $18-24 \mathrm{~h}$ at $37{ }^{\circ} \mathrm{C}$. Typical colonies were subcultured onto MacConkey agar (Oxoid, Basingstoke, UK) and were biochemically confirmed using API 20E system (BioMérieux, Marcyl'Étoile, France). Once identified, the isolates were preserved at $-70{ }^{\circ} \mathrm{C}$ in brain heart infusion broth containing $20 \%$ glycerol ( $\mathrm{vol} / \mathrm{vol}$ ) for further studies. Serotyping of $E$. coli isolates was performed using rapid diagnostic $E$. coli antisera sets (Denka Seiken Co., Japan) using 8 polyvalent, 43 monovalent somatic, and 22 flagellar antisera. Bacterial DNA for PCR analysis was prepared by boiling a bacterial culture in $300 \mu \mathrm{l}$ of distilled water for $10 \mathrm{~min}$, followed by centrifugation for $5 \mathrm{~min}$ at $10,000 \times g$. A volume of $1 \mu \mathrm{l}$ of the supernatant was used as a template for each $25 \mu \mathrm{l}$ PCR mixture.

\section{Antimicrobial susceptibility testing and detection of ES $\beta L$}

The susceptibility of isolates to 10 different antimicrobial agents was determined by disc diffusion assay as described by Clinical and Laboratory Standards Institute (CLSI) [7]. According to the measurement of inhibition zones, tested strains were evaluated as susceptible or resistant. The following antimicrobial discs (Oxoid, Basingstoke, UK) were used: gentamicin (GN, $10 \mu \mathrm{g})$, kanamycin (KAN, $30 \mu \mathrm{g}$ ), ampicillin (AMP, $10 \mu \mathrm{g}$ ), cefotaxime (CTX, $30 \mu \mathrm{g}$ ), nalidixic acid (NA, $30 \mu \mathrm{g})$, ciprofloxacin (CIP, $5 \mu \mathrm{g}$ ), tetracycline (TET, $30 \mu \mathrm{g}$ ), sulfamethoxazoletrimethoprim (STX, $25 \mu \mathrm{g})$, chloramphenicol $(\mathrm{C}, 30 \mu \mathrm{g})$, and streptomycin $(\mathrm{S}, 10 \mu \mathrm{g})$. The isolates were defined as multidrug-resistant APEC if they exhibited resistance to at least one agent in three or more antimicrobial categories [8]. Escherichia coli strain ATCC 25922 was used as a reference strain for susceptibility test. All cefotaximeresistant isolates were confirmed for the production of extended-spectrum beta-lactamase (ES $\beta \mathrm{L}$ ) by using the double-disk synergy test (DDST) following recommendation and interpretations of CLSI standards [7].

\section{Detection of integrons and characterization of associated gene cassettes}

The presence of integrons among APEC isolates was assayed using primers hep35 and hep36 that amplify conserved regions of integron-encoded integrase genes intI1, intI2, and intI3 using published PCR protocols [9]. Integron-positive isolates were characterized for the integron class using integron class-specific primers and PCR conditions previously described [10]. Further characterization of gene cassette content within integron classes was determined using primers $5^{\prime} \mathrm{CS} / 3^{\prime} \mathrm{CS}$ and hep74/hep51 for amplification of gene cassettes within integron classes 1 and 2, respectively as published [11, 12]. Samples with similar amplicon size were further subjected to restriction enzyme HinfI or RsaI [12] following manufacturer instructions (New England Biolabs, UK) and fragments obtained were separated on a $2.5 \%$ agarose gel. Isolates with similar polymorphism patterns were considered to harbor similar gene cassettes. Amplification products of samples with unique amplification products and one representative sample from samples with similar restriction patterns were purified from the agarose gel using QIA quick Gel Extraction Kit (Qiagen, USA) and sequenced using ABI Prism 377 automated sequencer (Applied Biosystems). All sequence results were compared with the available sequences in GenBank (http://www.ncbi.nlm. nih.gov/BLAST). 


\section{Detection of antimicrobial resistance genes outside the integron cassettes}

Different PCR protocols were applied to detect specific genetic determinants corresponding to the resistance phenotype using Applied Biosystems 96-well thermal cycler and PCR conditions suggested by the referenced authors. These determinants included those encoding resistance to tetracycline (tet $A, \operatorname{tet} B$, tet $C$, tet $D$, tet $E$, and tet $G$ ) [13], chloramphenicol (cat1, cat2, cat3, cmlA, and cmlB) [14], streptomycin (strA-strB) [15], Kanamycin (aphA1 and aphA2) [16], and sulfonamide including sul1, sul2 [17], and sul3 [18]. The PCR amplification products were separated by agarose gel electrophoresis and visualized by ethidium bromide staining. Resistance to ciprofloxacin was assayed by determining mutations in DNA gyrase subunit A (gyrA) and topoisomerase IV subunit $\mathrm{C}(\operatorname{ParC})$ in the quinolone resistance determining region (QRDR) using protocol previously described [19]. The resulting PCR amplicons were purified using QIA quick Gel Extraction Kit (Qiagen, USA) and bi-directionally sequenced using same primers. Strains that exhibited negative results for mutations in QRDR were screened for plasmid-mediated quinolone resistance (PMQR) including qnrA, qnrB, qnrS [20], qnrD [21], and $a a c\left(6^{\prime}\right)-I b-c r$ [22]. Ampicillin-resistant isolates were screened for the $\beta$-Lactamases genes $b l a_{\mathrm{TEM}}$ and $b l a_{\mathrm{SHV}}$, and $b l a_{\mathrm{OXA}-1}$ using multiplex PCR protocol published [23]. The later protocol was used to screen potential ES $\beta \mathrm{L}-$ producing $E$. coli isolates that initially exhibited resistance to cefotaxime. These isolates were further screened for $b l a_{\mathrm{CTX}-\mathrm{M}}$ five phylogenetic groups (groups 1, 2, 8, 9, and 25) using multiplex PCR protocol previously described [24].

\section{Pulsed-field gel electrophoresis (PFGE)}

PFGE was performed to determine that isolates exhibiting similar antibiogram resistance profile and similar serotype are non-identical. PFGE for tested APEC isolates was performed using $\mathrm{XbaI}$ restriction enzyme according to the PulseNet protocol from the Centers for Disease Control and Prevention [25]. At least one band difference was required to distinguish between pulsotypes.

\section{Statistical analysis}

Differences in the occurrence of integrons in resistant and susceptible APEC strains were tested using the Chi square $\left(\chi^{2}\right)$ test. Differences among means with $P<0.05$ were considered as statistically significant. For the statistical analysis, intermediate resistant strains were considered as resistant.

\section{Results}

\section{APEC serotypes}

A total of 116 E. coli isolates were recovered from 400 samples from diseased chicken. Serotyping recovered isolates identified 15 different $E$. coli serotypes (Table 1). All isolates exhibiting similar serotype and antimicrobial resistance patterns were confirmed to be non-duplicates as confirmed by PFGE. Among identified serotypes, O78 was found to be the most prevalent serotype (27.6\%).

\section{Antimicrobial resistance patterns and ES $\beta$ L phenotype}

Antibiotic susceptibility of 116 APEC isolates against 10 different antimicrobial drugs is presented in Table 2. The highest frequencies of resistance detected were those against ampicillin (100\%), tetracycline (93.1\%), nalidixic acid (84.5\%), chloramphenicol (84.5\%), kanamycin (69.0\%), sulfamethoxazole-trimethoprim (58.6\%), cefotaxime (58.6\%), streptomycin $(50.0 \%)$, gentamicin (48.3\%), and ciprofloxacin (41.4\%). A diversity of resistance patterns observed among tested $E$. coli isolates is shown in Table 1 . Screening the potential ES $\beta$ L producers confirmed that all cefotaxime-resistant isolates to be ES $\beta L$ producers $(68 / 68,100 \%)$.

\section{Distribution of integrons and associated gene cassettes}

Of the 116 isolates tested, 34 isolates (29.3\%) representing six serotypes were integron positive (Table 1). All integron-harboring $E$. coli isolates were multidrug resistant. Integron-positive isolates were significantly more resistant to streptomycin, kanamycin, gentamicin, and sulfamethoxazole-trimethoprim than integron-negative isolates $(\mathrm{P}<0.05)$. Among integron-positive isolates, class 1 integrons were detected in 30 isolates (25.9\%) and class 2 in four isolates (3.4\%) (Table 1). None of the isolates possessed the combination of class 1 and class 2 integrons. Class 3 was absent in tested APEC isolates. Further characterization of gene cassettes by $\mathrm{PCR}$, restriction digestion, and sequencing revealed eight different cassette arrangements within class 1 integron and a single cassette arrangement within class 2 integron. Among class 1 integron, the gene cassettes included those encoding resistance to trimethoprim ( $d f r A 1, d f r A 5, d f r A 7$, and $d f r A 12)$ and streptomycin (aadA1, aadA2, aadA5, and aadA23). A total of seven isolates harbored $\operatorname{aad} A 1+d f r A 1$ (20.6\%); six isolates carried $d f r A 7$ (17.6\%); five isolates had aadA1 (14.7\%); four isolates carried aadA5 (11.8\%); three isolates $(8.8 \%)$ contained $d f r A 5$; two isolate $(5.8 \%)$ carried aadA2 $+d$ frA12, two isolate (5.8\%) carried aadA23, and one $(2.9 \%)$ had $d f r A 1$. All class 2 integron-carrying isolates possessed the gene cassette array $d f r A 1$-sat2-aadA1 that encode resistance to trimethoprim, streptothricin, and streptomycin (Table 3).

\section{Distribution of antimicrobial resistance genes outside the integron cassettes}

Different frequencies of genes encoding resistance to tetracycline, chloramphenicol, ampicillin, streptomycin, 
Table 1 Overview and characteristics (MDR strains, integron presence, and antibiotic resistance) of the APEC strains classified per serotype

\begin{tabular}{|c|c|c|c|c|c|c|}
\hline \multirow[t]{2}{*}{ Serotype } & \multirow[t]{2}{*}{ No. of strains } & \multirow{2}{*}{$\begin{array}{l}\text { No. of MDR } \\
\text { strains }^{\mathrm{a}}\end{array}$} & \multirow{2}{*}{$\begin{array}{l}\text { No. of different antibiotic } \\
\text { resistance profiles }\end{array}$} & \multicolumn{3}{|c|}{ No. isolates carrying integrons } \\
\hline & & & & Class 1 & Class 2 & Total \\
\hline $\mathrm{O} 1: \mathrm{H} 7$ & $14(12.1 \%)$ & 6 & 14 & 2 & 0 & $2(14.3 \%)$ \\
\hline $\mathrm{O} 2: \mathrm{H} 6$ & $18(15.5 \%)$ & 14 & 18 & 6 & 0 & $6(33.3 \%)$ \\
\hline O8 & $2(1.7 \%)$ & 2 & 2 & 0 & 0 & $0(0 \%)$ \\
\hline $\mathrm{O} 111: \mathrm{H} 2$ & $4(3.4 \%)$ & 4 & 4 & 2 & 2 & $4(100 \%)$ \\
\hline $\mathrm{O} 26: \mathrm{H} 11$ & $6(5.2 \%)$ & 6 & 6 & 4 & 0 & $4(66.7 \%)$ \\
\hline $\mathrm{O} 44: \mathrm{H} 18$ & $2(1.7 \%)$ & 2 & 2 & 0 & 0 & $0(0 \%)$ \\
\hline $\mathrm{O} 55: \mathrm{H7}$ & $10(8.6 \%)$ & 8 & 6 & 0 & 0 & $0(0 \%)$ \\
\hline $\mathrm{O} 78$ & $32(27.6 \%)$ & 28 & 24 & 16 & 0 & 16 (50.0\%) \\
\hline O119:H6 & $6(5.2 \%)$ & 4 & 6 & 0 & 0 & $0(0 \%)$ \\
\hline 0124 & $4(3.4 \%)$ & 4 & 4 & 0 & 0 & $0(0 \%)$ \\
\hline O126:H2 & $6(5.2 \%)$ & 6 & 6 & 0 & 0 & $0(0 \%)$ \\
\hline 0127:H6 & $6(5.2 \%)$ & 4 & 6 & 0 & 2 & $2(33.3 \%)$ \\
\hline O128:H2 & $2(1.7 \%)$ & 2 & 2 & 0 & 0 & $0(0 \%)$ \\
\hline O142:H6 & $2(1.7 \%)$ & 0 & 2 & 0 & 0 & $0(0 \%)$ \\
\hline 0158 & $2(1.7 \%)$ & 0 & 2 & 0 & 0 & $0(0 \%)$ \\
\hline Total & 116 & 90 (77.6\%) & & $30(25.9 \%)$ & $4(3.4 \%)$ & 34 (29.3\%) \\
\hline
\end{tabular}

aDR strains multidrug-resistant strains that exhibited resistance to 3 or more different classes of antimicrobials

kanamycin, ciprofloxacin, cefotaxime, sulfonamide, and ES $\beta$ L production are reported in Table 2. Among tetracycline resistant isolates, $50(46.3 \%)$ isolates carried tet $A$ and 54 (50.0\%) isolates were positive for tetB. Our results also showed that four isolates (3.7\%) possessed both determinants. All isolates were negative for tet $C$, tet $D$, tet $E$, and tet $G$. Among the ampicillin-resistant isolates, $102(87.9 \%)$ isolates possessed $b l a_{\mathrm{TEM}}, 14$ (12.1\%) isolates carried $b l a_{\text {oxa1 }}$. None of these isolates carried $b l a_{\mathrm{SHV}}$ gene. The cat1 was the most common gene present among the chloramphenicol-resistant isolates $(86 / 98 ; 87.8 \%)$. Isolates $(n=68)$ that were resistant for sulfamethoxazole were tested for amplification of the sul genes. The sul2 and sul1 genes were present in $39(57.3 \%)$ and $23(33.8 \%)$ isolates, respectively. All ciprofloxacin-resistant APEC isolates were screened for mutations in QRDR of $g y r A$ and ParC by PCR and DNA sequencing. Our sequencing results showed that a total of $56.3 \%(27 / 48)$ of tested isolates possessed S83L mutation in $g y r A$. Four ciprofloxacin- resistant isolates harbored double mutations of $g y r A$ at residues 83 and 87 $(\mathrm{S} 83 \mathrm{~L}+\mathrm{D} 87 \mathrm{~N})$. One APEC isolate had a single mutation in parC encoding Ser80Ile. The PMQR were investigated in APEC isolates with no mutations in QRDR to explore further mechanisms of resistance. The $q n r A$, qnrB, and $q n r S$ genes were found in these isolates $(10,4$ and 2 isolates, respectively). None of the isolates were positive for $q u r D$ or $a a c\left(6^{\prime}\right)-I b-c r$ genes. The strA-strB genes encoding streptomycin resistance were examined to investigate streptomycin resistance determinants other than aadA present in the integron cassette and both genes were detected in $34(58.6 \%)$ isolates. The aphA1 and aphA2 gene markers, conferring kanamycin resistance were identified in a total of $65(81.3 \%)$ and $11(13.7 \%)$ isolates, respectively. The combined presence of both gene alleles was found in $4(5 \%)$ isolates. Screening ES $\beta$ L-producing E. coli isolates by multiplex PCR analysis revealed that 15 isolates were group in CTX-M-1 group. Group 9 enzymes were produced by two isolates. In addition, $b l a_{\mathrm{TEM}}$ and $b l a_{\text {OXA-1 }}$ genes were present in $20(29.4 \%)$ and $7(10.3 \%)$ ES $\beta$ L-producing $E$. coli isolates, respectively. A total of 24 isolates were observed to simultaneously carry $b l a_{\mathrm{TEM}}$ and contain alleles encoding group 1 CTX-M enzymes (Table 2).

\section{Discussion}

The emerging antimicrobial resistance among different APEC isolates has stimulated our interest in exploring the mechanisms of resistance and the frequencies of genetic determinants. In this study, the majority of recovered isolates belonged to serogroups $\mathrm{O} 1, \mathrm{O} 2, \mathrm{O} 78$. A similar observation was reported by other studies supporting the previous postulation that these serotypes are the most common serotypes in $E$. coli of avian origin worldwide [26].

Similar to the findings of previous studies $[2,5]$, most (84-100\%) APEC isolates were highly resistant to ampicillin, tetracycline, nalidixic acid, and chloramphenicol. 
Table 2 Molecular characterization of antimicrobial resistance genotypes among APEC isolates

\begin{tabular}{|c|c|c|c|c|}
\hline Antibiotic & $\begin{array}{l}\text { Antimicrobial } \\
\text { class }\end{array}$ & $\begin{array}{l}\text { Number of resistance } \\
\text { isolates }\end{array}$ & $\begin{array}{l}\text { Associated } \\
\text { genes tested }\end{array}$ & $\begin{array}{l}\text { Number of } \\
\text { positive isolates }\end{array}$ \\
\hline \multirow[t]{3}{*}{ Ampicillin } & \multirow[t]{3}{*}{ Penicillins } & \multirow[t]{3}{*}{$116(100 \%)$} & $b l a_{\mathrm{TEM}}$ & 102 \\
\hline & & & $b l a_{\mathrm{SHV}}$ & 0 \\
\hline & & & $b l a_{\text {oxa1 }}$ & 14 \\
\hline \multirow[t]{5}{*}{ Chloramphenicol } & \multirow[t]{5}{*}{ Phenicols } & \multirow[t]{5}{*}{$98(84.5 \%)$} & cat1 & 86 \\
\hline & & & cat2 & 4 \\
\hline & & & cat3 & 0 \\
\hline & & & $\mathrm{cm} / \mathrm{A}$ & 8 \\
\hline & & & $\mathrm{cm} / \mathrm{B}$ & 0 \\
\hline Streptomycin & Aminoglycosides & $58(50 \%)$ & strA-strB & 34 \\
\hline \multirow[t]{10}{*}{ Ciprofloxacin } & \multirow[t]{10}{*}{ Quinolones } & \multirow[t]{10}{*}{$48(41.4 \%)$} & $\mathrm{PMQR}^{\mathrm{a}}$ & \\
\hline & & & qnrA & 10 \\
\hline & & & $q n r B$ & 4 \\
\hline & & & anrs & 2 \\
\hline & & & qnrD & 0 \\
\hline & & & $a a c\left(6^{\prime}\right)-1 b-c r$ & 0 \\
\hline & & & $\mathrm{QRDR}^{\mathrm{b}}$ & \\
\hline & & & $\begin{array}{l}\mathrm{S} 83 \mathrm{~L} \\
(g y r A)\end{array}$ & 27 \\
\hline & & & $\begin{array}{l}\text { S83L + D87 N } \\
(g y r A)\end{array}$ & 4 \\
\hline & & & $\begin{array}{l}\text { S801 } \\
\text { (pyrC) }\end{array}$ & 1 \\
\hline \multirow{3}{*}{$\begin{array}{l}\text { Sulfamethoxazole- } \\
\text { trimethoprim }\end{array}$} & \multirow{3}{*}{$\begin{array}{l}\text { Potentiated } \\
\text { sulfonamides }\end{array}$} & \multirow[t]{3}{*}{$68(58.6 \%)$} & sul1 & 23 \\
\hline & & & sul2 & 39 \\
\hline & & & sul3 & 0 \\
\hline \multirow[t]{7}{*}{ Tetracycline } & \multirow[t]{7}{*}{ Tetracyclines } & \multirow[t]{7}{*}{$108(93.1 \%)$} & tetA & 50 \\
\hline & & & tetB & 54 \\
\hline & & & tetC & 0 \\
\hline & & & tetD & 0 \\
\hline & & & tetE & 0 \\
\hline & & & tet $G$ & 0 \\
\hline & & & tet $A+$ tet $B$ & 4 \\
\hline \multirow[t]{3}{*}{ Kanamycin } & \multirow[t]{3}{*}{ Aminoglycosides } & \multirow[t]{3}{*}{$80(69.0 \%)$} & aphA1 & 65 \\
\hline & & & aphA2 & 11 \\
\hline & & & $a p h A 1+a p h A 2$ & 4 \\
\hline \multirow[t]{9}{*}{ Cefotaxime (ESßL) } & \multirow[t]{9}{*}{ Cephalosporins } & \multirow[t]{9}{*}{$68(58.6 \%)$} & CTX-M (group 1) & 15 \\
\hline & & & CTX-M (group 2) & 0 \\
\hline & & & CTX-M (group 8) & 0 \\
\hline & & & CTX-M (group 9) & 2 \\
\hline & & & CTX-M (group 25) & 0 \\
\hline & & & $b / a_{\text {TEM }}$ & 20 \\
\hline & & & $b l a_{\mathrm{SHV}}$ & 0 \\
\hline & & & $b l a_{\text {oxa1 }}$ & 7 \\
\hline & & & CTX-M (group 1) $+b l a_{\mathrm{TEM}}$ & 24 \\
\hline
\end{tabular}

\footnotetext{
a Plasmid-mediated quinolone resistance
}

${ }^{\mathrm{b}}$ Quinolone resistance determining region 
Table 3 Distribution of class 1 and class 2 integrons among APEC isolates

\begin{tabular}{lll}
\hline $\begin{array}{l}\text { Integron } \\
\text { genotype }\end{array}$ & $\begin{array}{l}\text { Integron } \\
\text { class }\end{array}$ & $\begin{array}{l}\text { Number of positive } \\
\text { integron harboring isolates }\end{array}$ \\
\hline aadA1-dfrA1 & 1 & 7 \\
dfrA7 & 1 & 6 \\
aadA1 & 1 & 5 \\
aadA5 & 1 & 4 \\
dfrA5 & 1 & 3 \\
aadA2-dfrA12 & 1 & 2 \\
aadA23 & 1 & 2 \\
dfrA1 & 1 & 1 \\
dfrA1-sat2-aadA1 & 2 & 4 \\
Total & & 34 \\
\hline
\end{tabular}

Many (41-69\%) APEC isolates were resistant to streptomycin, gentamycin, kanamycin, sulfamethoxazole combined with trimethoprim, ciprofloxacin, and cefotaxime. Most of these antimicrobial agents are regularly used as prophylactic agents or as growth promoters in the poultry industry in Egypt.

In the present study, the proportion of integron carriage among APEC isolates is consistent with previous studies worldwide [10, 27]. In a study conducted in Egypt on APEC isolated from septicemic broilers, higher prevalence was reported for class 1 and 2 (46.6 and $9.6 \%$, respectively) [5]. Our results revealed that the genes found in class 1 and class 2 integrons encode for adenyltransferase conferring resistance to streptomycin and spectinomycin $(a a d A)$ and for a dihydrofolate reductase conferring resistance to trimethoprim $(d f r)$. These gene cassettes are the most frequently detectable genes from pathogenic and commensal $E$. coli from poultry farms and also from different animal, environmental, and human sources [4-6].

Among class 1 integron-harboring isolates, four different trimethoprim resistance genes (dfrA1, dfrA5, dfrA7, $d f r A 12$ ) and four streptomycin/spectinomycin resistance genes (aadA1, aadA2, aadA5, aadA23) were detected as gene cassettes in class 1 integrons. The aadA23 gene cassette detected in this study was first reported in 2005 in Brazil from Salmonella Agona strains isolated from a pig carcass [28]. In Egypt, this gene cassette was previously described among $E$. coli strains isolated from neonatal calf diarrhea [29]. To our knowledge, the first description of aadA23 in E. coli of avian origin. All class 2 integron carrying isolates processed the gene cassette array $d f r A 1$ sat2-aadA1 that is considered as the classical gene cassette found in class 2 integron among APEC strains [5, 30]. The absence of class 3 integron among our isolates corroborate previous studies $[5,30]$, suggesting the less significant role of this integron in dissemination of antimicrobial resistance among APEC.

We further assessed the presence of other genetic determinants located outside the integron that were previously proposed to be responsible for resistance to different antimicrobial agents. Among tetracycline-resistant isolates, tet $A$ and tet $B$ markers were the only tet genes reported in this study either in single or combined genes. These results supported the observation that these efflux genes are the most frequent tet genes found in Enterobacteriaceae [31]. The high prevalence of these variants might be attributed to their higher association with plasmids, mainly the conjugative ones or transposons [31], suggesting that these genes are the major genes implicated in the efflux mechanism in APEC leading to the resistance phenotype. The high prevalence of cat 1 among chloramphenicol-resistant isolates supports previous studies highlighting the crucial role of this allele in chloramphenicol resistance [16]. The combined presence of strA-strB determinants encoding two enzymes required for high level of streptomycin resistance [32] was assayed in this study as aadA gene observed in the integron has been proposed to confer low level of streptomycin [33]. In this study, the presence of the $\operatorname{str} A-s t r B$ gene pair among streptomycin-resistant was within the range reported among APEC strains isolated in Korea during the period 2000 to 2005 [34]. The high prevalence of aph $A 1$ among kanamycin-resistant isolates is consistent with other studies that proposed aphA1 to be the main neomycin/kanamycin resistance marker $[16,35]$. The predominance of $b l a_{\text {TEM }}$ gene (87.9\%) among ampicillinresistant isolates corroborates a previous study that suggested $b l a_{\text {TEM }}$ gene to be the most common $\beta$-lactamase responsible for ampicillin resistance [34].

Resistance to quinolone in APEC is mainly mediated by spontaneous mutations in the QRDR of gyrA and parC genes [2, 34]. Nonetheless, in a previous study conducted among APEC isolates in Egypt, these substitutions in QRDR genes were not screened and only PMQR genes were investigated [5]. Our results revealed that among ciprofloxacin-resistant isolates, the mutation in $\mathrm{gyr} A$ (S83L) involved in fluoroquinolone resistance was the most prevalent genetic determinant, an observation previously reported in a study conducted among quinoloneresistant APEC isolates in Korea [34].

One of the most striking findings from this study was the high prevalence of ES $\beta \mathrm{L}$-producing isolates recovered from broilers $(58.6 \%)$. This represents a serious public health threats attributed to the ability of these bacteria to hydrolyze third-generation cephalosporins that are commonly used to treat serious infections and the potential transfer and spread of these resistance genes to human through food chain, direct contact, or the environment 
[36-38]. The higher frequency of CTX-M-1-group in this study supports recent reports that postulated this group to the most predominant CTX-M group among ES $\beta \mathrm{L}-$ producing APEC in Egypt or worldwide [5, 39, 40].

\section{Conclusions}

Our results reported high rates of antibiotic resistance among APEC isolates recovered from different poultry farms in Egypt, including those drugs of broad-spectrumactivity such as $\beta$-lactams, third generation cephalosporins, and quinolones. Furthermore, our findings suggested diverse genetic makeup involved in antimicrobial resistance phenotype. Indeed, integron-mediated resistance could explain only a part of the resistance profile of the isolates as other independent genes were significantly observed. This diversity in distribution of resistance determinants could be responsible for the high resistance profiles recorded and the potential spread of antimicrobial resistance determinants among APEC. These advices more restriction in antimicrobials use in poultry farms among veterinarians to prevent and control the spread of antimicrobial-resistant bacteria and their genetic determinants. Consequently, our future studies will be directed to study the clonal link and compare the overlapping characteristics of recovered APEC isolates with human ExPEC (extra-intestinal pathogenic E. coli) to confirm the zoonotic potential of APEC, including their potential ability to transfer antimicrobial resistance to human.

\section{Abbreviations \\ APEC: avian-pathogenic Escherichia coli; AMR: antimicrobial resistance; CLSI: Clinical and Laboratory Standards Institute; EMB: eosin methylene blue; ES $\beta$ L: extended-spectrum beta-lactamase; ExPEC: extra-intestinal pathogenic $E$. coli; MDR: multiple drug resistance; PFGE: pulsed-field gel electrophoresis; PMQR: plasmid-mediated quinolone resistance; QRDR: quinolone resistance determining region.}

\section{Authors' contributions}

ME conceived and designed the study, performed the tests, analyzed and interpreted the data, and wrote the manuscript. AA and NA substantially contributed to collection of samples, isolation of strains and participated in data analysis, and revision of the manuscript. All authors read and approved the final manuscript.

\footnotetext{
Author details

${ }^{1}$ Department of Bacteriology, Mycology and Immunology, Faculty of Veterinary Medicine, Mansoura University, Mansoura 35516, Egypt. ${ }^{2}$ Department of Poultry diseases, Faculty of Veterinary Medicine, Mansoura University, Mansoura 35516, Egypt. ${ }^{3}$ Foodborne Pathogens, Scientific Institute of Public Health, Juliette Wytsmanstraat 14, 1050 Brussels, Belgium.

\section{Acknowledgements}

The authors would like to thank Dr. Eman Abo Elfadl at the Department of Animal Husbandry and Development of Animal Wealth, Faculty of Veterinary Medicine, Mansoura University for her technical help during this study. Dr. Mohamed Elhadidy is currently a visiting research fellow at Scientific Institute of Public Health in Brussels funded by Federal Science Policy Office.
}

\section{Competing interests}

The authors declare that they have no competing interests.

\section{Funding}

The authors declare that they did not have any funding source or grant to support their research work.

Received: 2 September 2016 Accepted: 17 November 2016

Published online: 25 November 2016

\section{References}

1. Dho-Moulin M, Fairbrother JM. Avian pathogenic Escherichia coli (APEC). Vet Res. 1999;30:299-316.

2. Yang H, Chen S, White DG, Zhao S, McDermott P, Walker R, Meng J. Characterization of multiple-antimicrobial-resistant Escherichia coli isolates from diseased chickens and swine in China. J Clin Microbiol. 2004;42:3483-9.

3. Bean DC, Livermore DM, Hall LM. Plasmids imparting sulfonamide resistance in Escherichia coli: implications for persistence. Antimicrob Agents Chemother. 2009;53:1088-93.

4. Karczmarczyk M, Walsh C, Slowey R, Leonard N, Fanning S. Molecular characterization of multidrug-resistant Escherichia coli isolates from Irish cattle farms. Appl Environ Microbiol. 2011;77:7121-7.

5. Ahmed AM, Shimamoto T, Shimamoto T. Molecular characterization of multidrug-resistant avian pathogenic Escherichia coli isolated from septicemic broilers. Int J Med Microbiol. 2013;303:475-83.

6. Cocchi S, Grasselli E, Gutacker M, Benagli C, Convert M, Piffaretti JC. Distribution and characterization of integrons in Escherichia coli strains of animal and human origin. FEMS Immunol Med Microbiol. 2007;50:126-32.

7. Clinical and Laboratory Standards Institute. Performance standards for antimicrobial susceptibility testing; 20th informational supplement M100-S20. Wayne: CLSI; 2010.

8. Magiorakos AP, Srinivasan A, Carey RB, Carmeli Y, Falagas ME, Giske CG, Harbarth S, Hindler JF, Kahlmeter G, Olsson-Liljequist B, Paterson DL, Rice LB, Stelling J, Struelens MJ, Vatopoulos A, Weber JT, Monnet DL. Multidrug-resistant, extensively drug-resistant and pandrug-resistant bacteria: an international expert proposal for interim standard definitions for acquired resistance. Clin Microbiol Infect. 2012;18(268-81):27.

9. Nagachinta $S$, Chen J. Integron-mediated antibiotic resistance in Shiga toxin-producing Escherichia coli. J Food Prot. 2009;72:21-7.

10. Povilonis J, Seputiene V, Ruzauskas M, Siugzdiniene R, Virgailis M, Pavilonis A, Suziedeliene E. Transferable class 1 and 2 integrons in Escherichia coli and Salmonella enterica isolates of human and animal origin in Lithuania. Foodborne Pathog Dis. 2010;7:1185-92.

11. Levesque $C$, Piche L, Larose C, Roy PH. PCR mapping of integrons reveals several novel combinations of resistance genes. Antimicrob Agents Chemother. 1995;39:185-91.

12. White PA, Mclver CJ, Deng Y, Rawlinson WD. Characterisation of two new gene cassettes, aadA5 and dfrA17. FEMS Microbiol Lett. 2000;182:265-9.

13. Ng LK, Martin I, Alfa M, Mulvey M. Multiplex PCR for the detection of tetracycline resistant genes. Mol Cell Probes. 2001;15:209-15.

14. Chen S, Zhao S, White D, Schroeder CM, Lu R, Yang H, McDermott PF, Ayers S, Meng J. Characterization of multiple-antimicrobial-resistant Salmonella serovars isolated from retail meats. Appl Environ Microbiol. 2004;70:1-7.

15. Tamang MD, Oh JY, Seol SY, Kang HY, Lee JC, Lee YC, Cho DT, Kim J. Emergence of multidrug-resistant Salmonella enterica serovar Typhi associated with a class 1 integron carrying the dfrA7 gene cassette in Nepal. Int J Antimicrob Agents. 2007;30:330-5.

16. Maynard C, Fairbrother JM, Bekal S, Sanschagrin F, Levesque RC, Brousseau R, Masson L, Lariviere S, Harel J. Antimicrobial resistance genes in enterotoxigenic Escherichia coli 0149:K91 isolates obtained over a 23-year period from pigs. Antimicrob Agents Chemother. 2003;47:3214-21.

17. Kerrn MB, Klemmensen T, Frimodt-Moller N, Espersen F. Susceptibility of Danish Escherichia coli strains isolated from urinary tract infections and bacteraemia, and distribution of sul genes conferring sulphonamide resistance. J Antimicrob Chemother. 2002;50:513-6. 
18. Hammerum AM, Sandvang D, Andersen SR, Seyfarth AM, Porsbo LJ, Frimodt-Moller N, Heuer OE. Detection of sul1, sul2 and sul3 in sulphonamide resistant Escherichia coli isolates obtained from healthy humans, pork and pigs in Denmark. Int J Food Microbiol. 2006;106:235-7.

19. Everett MJ, Jin YF, Ricci V, Piddock LJV. Contribution of individual mechanisms to fluoroquinolone resistance in 36 Escherichia coli strains isolated from humans and animals. Antimicrob Agents Chemother. 1996;40:2380-6

20. Cattoir V, Poirel L, Rotimi V, Soussy CJ, Nordmann P. Multiplex PCR for detection of plasmid-mediated quinolone resistance qur genes in ESBL-producing enterobacterial isolates. J Antimicrob Chemother. 2007;60:394-7.

21. Cavaco LM, Hasman H, Xia S, Aarestrup FM. qnrD, a novel gene conferring transferable quinolone resistance in Salmonella enterica serovar Kentucky and Bovismorbificans strains of human origin. Antimicrob Agents Chemother. 2009;53:603-8.

22. Park CH, Robicsek A, Jacoby GA, Sahm D, Hooper DC. Prevalence in the United States of aac (6')-lb-cr encoding a ciprofloxacin-modifying enzyme. Antimicrob Agents Chemother. 2006;50:3953-5.

23. Colom K, Pérez J, Alonso R, Fernández-Aranguiz A, Lariño E, Cisterna R. Simple and reliable multiplex PCR assay for detection of blaTEM, bla(SHV) and blaOXA-1 genes in Enterobacteriaceae. FEMS Microbiol Lett. 2003;223:147-51.

24. Woodford N, Fagan EJ, Ellington MJ. Multiplex PCR for rapid detection of genes encoding CTX-M extended-spectrum (beta)-lactamases. J Antimicrob Chemother. 2005;57:154-5.

25. Ribot EM, Fair MA, Gautom R, Cameron DN, Hunter SB, Swaminathan B, Barrett TJ. Standardization of pulsed-field gel electrophoresis protocols for the subtyping of Escherichia coli 0157:H7, Salmonella, and Shigella for PulseNet. Foodborne Pathog Dis. 2006;3:59-67.

26. Ewers C, Janssen T, Kiessling S, Philipp HC, Wieler LH. Molecular epidemiology of avian pathogenic Escherichia coli (APEC) isolated from colisepticemia in poultry. Vet Microbiol. 2004;104:91-101.

27. Oosterik LH, Peeters L, Mutuku I, Goddeeris BM, Butaye P. Susceptibility of avian pathogenic Escherichia coli from laying hens in Belgium to antibiotics and disinfectants and integron prevalence. Avian Dis. 2014;58:271-8.

28. Michael GB, Cardoso M, Schwarz S. Class 1 integron-associated gene cassettes in Salmonella enterica subsp. enterica serovar Agona isolated from pig carcasses in Brazil. J Antimicrob Chemother. 2005;55:776-9.

29. Ahmed AM, Younis EE, Osman SA, Ishida Y, El-Khodery SA, Shimamoto T. Genetic analysis of antimicrobial resistance in Escherichia coli isolated from diarrheic neonatal calves. Vet Microbiol. 2009;136:397-402.
30. Cavicchio L, Dott G, Giacomelli M, Giovanardi D, Grilli G, Franciosini MP, Trocino A, Piccirillo A. Class 1 and class 2 integrons in avian pathogenic Escherichia coli from poultry in Italy. Poult Sci. 2015;94:1202-8.

31. Chopra I, Roberts M. Tetracycline antibiotics: mode of action, applications, molecular biology, and epidemiology of bacterial resistance. Microbiol Mol Biol Rev. 2001;65:232-60.

32. Chiou CS, Jones AL. Expression and identification of the strA-strB gene pair from streptomycin-resistant Erwinia amylovora. Gene. 1995;152:47-51.

33. Sunde $M$, Norstrom $M$. The genetic background for streptomycin resistance in Escherichia coli influences the distribution of MICs. J Antimicrob Chemother. 2005;56:87-90.

34. Kim TE, Jeong YW, Cho S, Kim SJ, Kwon HJ. Chronological study of antibiotic resistances and their relevant genes in Korean avian pathogenic Escherichia coli isolates. J Clin Microbiol. 2007;45:3309-15.

35. Pezzella C, Ricci A, DiGiannatale E, Luzzi I, Carattoli A. Tetracycline and streptomycin resistance genes, transposons, and plasmids in Salmonella enterica isolates from animals in Italy. Antimicrob Agents Chemother. 2004;48:903-8

36. Kluytmans AJW, Overdevest ITMA, Willemsen I, Kluytmans-van den Bergh MF, van der Zwaluw K, Heck M, Rijnsburger M, Vandenbroucke-Grauls CM, Savelkoul PH, Johnston BD, Gordon D, Johnson JR. Extended-spectrum $\beta$-lactamase producing Escherichia coli from retail chicken meat and humans: comparison of strains, plasmids, resistance genes, and virulence factors. Clin Infect Dis. 2013;56:478-87.

37. Huijbers PMC, Graat EAM, Haenen APJ, van Santen MG, van Essen-Zandbergen A, Mevius DJ, van Duijkeren E, van Hoek AH. Extended-spectrum $\beta$-lactamase- and AmpC $\beta$-lactamase-producing Escherichia coli in broilers and people living and/or working on broiler farms: prevalence, risk factors, and molecular characteristics. J Antimicrob Chemother. 2014:69:2669-75

38. Voets GM, Fluit AC, Scharringa J, Schapendonk C, van den Munckhof T, Leverstein-van Hall MA, Stuart JC. Identical plasmid AmpC betalactamase genes and plasmid types in E. coli isolates from patients and poultry meat in the Netherlands. Int J Food Microbiol. 2013;167:359-62.

39. Abdallah HM, Reuland EA, Wintermans BB, Al Naiemi N, Koek A, Abdelwahab AM, Ammar AM, Mohamed AA, Vandenbroucke-Grauls CM. Extended Spectrum $\beta$ Lactamases and/or CarbapenemasesProducing Enterobacteriaceae isolated from retail chicken meat in Zagazig, Egypt. Plos ONE. 2015;18:e0136052.

40. Livermore DM, Hawkey PM. CTX-M: changing the face of ESBLs in the UK. J Antimicrob Chemother. 2005:56:451-4.

\section{Submit your next manuscript to BioMed Central and we will help you at every step:}

- We accept pre-submission inquiries

- Our selector tool helps you to find the most relevant journal

- We provide round the clock customer support

- Convenient online submission

- Thorough peer review

- Inclusion in PubMed and all major indexing services

- Maximum visibility for your research

Submit your manuscript at www.biomedcentral com/submit
BioMed Central 